OPEN ACCESS

Edited by:

Antje Kroner,

Medical College of Wisconsin,

United States

Reviewed by:

Rishein Gupta,

University of Texas at San Antonio,

United States

Bruce Hostager,

The University of lowa, United States

Steven F. Abcouwer,

Michigan Medicine, United States

*Correspondence:

Carlos S. Subauste

carlos.subauste@case.edu

Specialty section:

This article was submitted to

Multiple Sclerosis and

Neuroimmunology,

a section of the journal

Frontiers in Immunology

Received: 28 May 2019 Accepted: 02 December 2019 Published: 17 December 2019

Citation:

Subauste CS (2019) The CD40-ATP-P2X Receptor Pathway: Cell to Cell Cross-Talk to Promote Inflammation and Programmed Cell

Death of Endothelial Cells.

Front. Immunol. 10:2958. doi: 10.3389/fimmu.2019.02958

\section{The CD40-ATP-P2X 7 Receptor Pathway: Cell to Cell Cross-Talk to Promote Inflammation and Programmed Cell Death of Endothelial Cells}

\author{
Carlos S. Subauste ${ }^{1,2 *}$ \\ ${ }^{1}$ Division of Infectious Diseases and HIV Medicine, Department of Medicine, Case Western Reserve University, Cleveland, \\ $\mathrm{OH}$, United States, ${ }^{2}$ Department of Pathology, Case Western Reserve University, Cleveland, $\mathrm{OH}$, United States
}

Extracellular adenosine 5'-triphosphate (ATP) functions not only as a neurotransmitter but is also released by non-excitable cells and mediates cell-cell communication involving glia. In pathological conditions, extracellular ATP released by astrocytes may act as a "danger" signal that activates microglia and promotes neuroinflammation. This review summarizes in vitro and in vivo studies that identified CD40 as a novel trigger of ATP release and purinergic-induced inflammation. The use of transgenic mice with expression of CD40 restricted to retinal Müller glia and a model of diabetic retinopathy (a disease where the CD40 pathway is activated) established that CD40 induces release of ATP in Müller glia and triggers in microglia/macrophages purinergic receptor-dependent inflammatory responses that drive the development of retinopathy. The CD40-ATP-P2X 7 pathway not only amplifies inflammation but also induces death of retinal endothelial cells, an event key to the development of capillary degeneration and retinal ischemia. Taken together, CD40 expressed in non-hematopoietic cells is sufficient to mediate inflammation and tissue pathology as well as cause death of retinal endothelial cells. This process likely contributes to development of degenerate capillaries, a hallmark of diabetic and ischemic retinopathies. Blockade of signaling pathways downstream of CD40 operative in non-hematopoietic cells may offer a novel means of treating diabetic and ischemic retinopathies.

Keywords: CD40, glia, retina, endothelial cell, ATP, cytokine, diabetes

\section{INTRODUCTION}

Glia orchestrate homeostasis in neural tissue through cell-to-cell interactions. Communication among glial subsets and communication between glia and other cells of the nervous system are also important during the development of disorders with an inflammatory component. ATP released by astrocytes appears to cause neuroinflammation by activating pro-inflammatory responses in microglia (1). Retinopathies caused by diabetes and ischemia are driven to a significant extent by chronic inflammation (2-4). The CD40 pathway is activated in these retinopathies and CD40 has emerged as a central mediator of inflammatory responses and pathology in these disorders (5-7). Herein I will review our work that identified CD40 expressed in retinal Müller glia as a trigger 
for secretion of ATP that in turn engages the $\mathrm{P} 2 \mathrm{X}_{7}$ receptor leading to pro-inflammatory cytokine production by monocyte/macrophages/microglia and programmed cell death of retinal endothelial cells $(7,8)$. Through this process, CD40 present in a non-hematopoietic cell amplifies inflammation and causes tissue pathology.

\section{CD40}

CD40 is a member of the TNF receptor superfamily that is expressed in various hematopoietic and non-hematopoietic cells including antigen-presenting cells (B cells, dendritic cells, and monocyte/macrophages), endothelial cells, epithelial cells, vascular smooth muscle cells, retinal Müller glia, fibroblasts, and neurons (6, 9-13). CD154 (CD40 ligand) is expressed primarily on activated $\mathrm{CD} 4^{+} \mathrm{T}$ cells, platelets, and is also present as a biologically active soluble protein present in plasma $(14,15)$.

Studies in patients with congenital absence of functional CD154 (Hyper IgM syndrome, X-HIM) provide clinical evidence for the central role of this pathway in adaptive immunity (16). CD40-CD154 interaction promotes dendritic cell maturation inducing licensing of these cells for efficient $\mathrm{T}$ cell priming $(14,17,18)$. This pathway stimulates IL-12 secretion by dendritic cells that in turn promotes $\mathrm{CD} 4^{+} \mathrm{T}$ cell differentiation into Th1 cells $(14,17,18)$. It also supports $\mathrm{CD}^{+}$cytotoxic $\mathrm{T}$ lymphocytes (CTL) development and prevents CTL exhaustion (19). CD40-CD154 interaction promotes pro-inflammatory cytokine production by macrophages and activates effector functions that are central to control of intracellular pathogens $(14,18)$. Indeed, the most important clinical feature of patients with X-HIM is the increased susceptibility to opportunistic infections normally controlled by cell-mediated immunity (16). The CD40-CD154 pathway is also central for humoral immune responses including $B$ cell proliferation, germinal center formation, antibody production, immunoglobulin class switch, and the generation of B cell memory $(14,17,18)$.

In contrast to hematopoietic cells, little is known about the physiologic role of CD40 in non-hematopoietic cells. It has been proposed that CD40 promotes survival of neurons in the brain since old $\mathrm{CD} 40^{-/-}$mice (16 months of age) have reduced expression of neurofilament isoforms and exhibit evidence compatible with increased neuronal programmed cell death (TUNEL ${ }^{+}$neurons) (12). In addition, in developing neural tissue, CD40 promotes axon growth in sympathetic neurons and has effects on dendrite growth that vary depending on the class of neurons: $\mathrm{CD} 40$ promotes dendrite growth in hippocampal excitatory neurons while it suppresses dendrite growth in striatal inhibitory neurons $(20,21)$. It is not known whether CD40 regulates the development and survival of retinal neurons. Moreover, the physiologic function of CD40 expressed in non-hematopoietic compartments in other organs is unclear. This may be explained by the low levels of CD40 expression in these compartments under basal conditions. In contrast, CD40 is upregulated in various inflammatory disorders and, through ligand engagement, CD40 triggers pro-inflammatory responses in endothelial cells, vascular smooth muscle cells and epithelial cells that play a key role in the pathogenesis of various disorders such as inflammatory bowel disease, systemic lupus erythematosus, rheumatoid arthritis, multiple sclerosis, graft rejection, and atherosclerosis $(22,23)$. These responses include increased protein expression of adhesion molecules, chemokines, metalloproteinases, and tissue factor $(22,23)$. The effects of CD40 ligation on retinal non-hematopoietic cells are discussed below.

\section{DIABETIC AND OTHER ISCHEMIC RETINOPATHIES}

Diabetes mellitus has become one of the most important health problems in the world. It is estimated that there are 422 million patients with diabetes worldwide (World Health Organization; www.who.int/diabetes/global-report). Diabetic retinopathy (DR) is a major complication of diabetes and eventually occurs in $\sim 35 \%$ of patients with diabetes (24). In addition, DR is the most common cause of vision loss among working-age adults in developed countries (25). The development of DR appears to be multifactorial and mechanisms such as oxidative stress, increased polyol and hexosamine pathway flux, protein kinase $\mathrm{C}$ activation, increased formation of advanced glycation-end products and alterations in systemic and local lipid metabolism have been linked to the development of the disease $(26,27)$. Ample experimental data indicate that low-grade chronic inflammation also plays an important role in the development of DR (2-4).

The vitreous of patients with DR (28) and retinal endothelial cells from diabetic humans and rodents exhibit increased expression of ICAM-1, an event that promotes adherence of leukocytes to the retinal vasculature (leukostasis) $(29,30)$. This phenomenon is important since blockade of ICAM-1CD18 interaction diminishes the development of degenerate capillaries in diabetic mice (31). These structures are a hallmark of early diabetic retinopathy and are formed as a consequence of the death of endothelial cells and pericytes, leading to the transformation of capillaries into collapsed sheaths of collagen/extracellular matrix structures that lack blood flow (32). The ensuing ischemia can promote transition to proliferative DR (PDR) that is characterized by retinal neovascularization. DR is also accompanied by increased expression of TNF- $\alpha$ and IL- $1 \beta$ (33-36). Microglia/macrophages express TNF- $\alpha$ in the diabetic retina (34). TNF- $\alpha$ and IL- $1 \beta$ play a pathogenic role in DR since they contribute to diabetes-induced degeneration of retinal capillaries $(37,38)$. Inducible nitric oxide synthase (NOS2) is expressed in the retinas of patients with DR and of diabetic rodents $(39,40)$. Furthermore, diabetic NOS2 ${ }^{-/-}$mice have reduced retinal leukostasis and capillary degeneration $(41,42)$. CCL2 levels are increased in the vitreous fluid in patients with PDR (43) and in retinas of diabetic rodents (44). This chemokine appears to play a pathogenic role in DR since there is a correlation between CCL2 protein levels in the vitreous with the severity of DR (43).

Ischemic retinopathies including those caused by central retinal artery occlusion, retinal vein occlusion, and retarded retinal vascular development in premature infants are important causes of permanent visual impairment and blindness in 
adults and children (45-47). Like DR, inflammatory responses including TNF- $\alpha$, IL- $1 \beta$, nitro-oxidative stress, and chemokines likely play an important role in the pathogenesis of these diseases (48). Retinal injury induced by ischemia/reperfusion (I/R) is a commonly used animal model of ischemic retinopathy (49). I/Rinduced retinopathy is characterized by retinal inflammation, loss of ganglion cells, and development of capillary degeneration (49). I/R of the retina causes upregulation of ICAM-1, TNF- $\alpha$, IL1 , NOS2, and COX-2 $(5,49-53)$. These responses are pathogenic since approaches to inhibit them are protective against retinal pathology (50-54).

\section{CD40 IN THE DEVELOPMENT OF DIABETIC AND I/R-INDUCED RETINOPATHIES}

CD40 is expressed in the retina at the level of endothelial cells, Müller glia (important macroglia in the retina), microglia, ganglion cells, and retinal pigment epithelial cells (5, 6, 55, 56). The levels of CD40 expression are low under basal conditions. However, induction or upregulation of CD40 expression is a feature of inflammatory disorders driven by CD40 (57). Indeed, CD40 mRNA is upregulated in the retina of mice with diabetes and mice subjected to retinal $\mathrm{I} / \mathrm{R}(5,6)$. Immunohistochemistry and flow cytometry studies to assess protein expression revealed that CD40 is upregulated in retinal endothelial cells, Müller glia and microglia of diabetic mice (6). Importantly, $\mathrm{CD} 40^{-/-}$mice are protected from I/R-induced retinopathy and early diabetic retinopathy $(5,6)$.

Ligation of CD40 in retinal Müller glia upregulates ICAM1, CCL2, NOS2 at the protein level and stimulates $\mathrm{PGE}_{2}$ production $(5,6,58)$. CD40 ligation in retinal endothelial cells upregulates ICAM-1 and CCL2 protein levels $(5,6,58)$. Retinal endothelial cells also produce CXCL1 following CD40 stimulation, a response that is markedly potentiated by a low concentration of IL-1 $\beta$ (5).

CD40 is central for the development of retinal inflammation and retinopathy induced by $I / R$. In contrast to wild-type mice, $\mathrm{CD} 40^{-/-}$mice subjected to $\mathrm{I} / \mathrm{R}$ are protected from upregulation of ICAM-1, CXCL1, NOS2, and COX-2 mRNA levels (5). The reduced expression of NOS2 and COX-2 is explained at least in part by diminished recruitment of $\mathrm{NOS}^{+}$ $\mathrm{COX}-2^{+}$leukocytes into the retina of $\mathrm{CD} 40^{-/-}$mice (5). Importantly, the loss of ganglion cells and the development of capillary degeneration are markedly attenuated in ischemic retinas of $\mathrm{CD} 40^{-/-}$mice (5). The protection from development of ischemic retinopathy observed in $\mathrm{CD} 40^{-/-}$mice is likely explained by diminished leukocyte infiltration and reduced expression of pro-inflammatory molecules since blockade of ICAM-1, NOS2, or COX-2 protect from retinal pathology after ischemia $(51,52,54)$. Altogether, CD40 is a central mediator of inflammation and neuro-vascular degeneration after I/Rinduced injury of the retina. The model that likely explains these findings is as follows: ischemia-induced activation of CD40 in retinal endothelial cells triggers ICAM-1 and KC/CXCL1 upregulation leading to recruitment of NOS2 and COX-2expressing leukocytes that would in turn promote neurovascular degeneration in the retina (5). However, it is also possible that Müller glia from ischemic retinas could be a source of increased NOS2 and/or COX-2 expression after activation via CD40.

The upregulation of CD40 and CD154 indicate that this pathway is activated in diabetes. CD40 protein expression in increased in the retina of diabetic mice and in the kidneys of patients with diabetic nephropathy $(6,59)$. CD40 mRNA levels are upregulated in the retinas of diabetic mice (6). Peripheral blood mononuclear cells from poorly controlled patients with type I diabetes exhibit increased mRNA levels of the functional type I isoform of CD40 (60). It is not known whether changes in micro RNA that control CD40 transcription [i.e., miR-155, miR424 , miR-503 $(61,62)]$ explain the upregulation of CD40 mRNA. In addition, CD154 protein levels are elevated in the blood from patients with diabetic microangiopathy and mice with diabetes $(7,63,64)$. CD154 upregulation is biologically relevant since serum CD154 from diabetics triggers pro-inflammatory responses in endothelial cells and monocytes (63). It is likely that CD154 levels are also increased in the retina because microthrombosis occurs in diabetic retinopathy and activated platelets express CD154 (65).

CD40 is relevant to DR since diabetic $\mathrm{CD} 40^{-/-}$mice are protected from upregulation of ICAM-1 in retinal endothelial cells, leukostasis, upregulation of TNF- $\alpha$, IL-1 $\beta$, and NOS2 mRNA levels, retinal protein nitration and elevated CCL2 mRNA levels in the retina $(6,7,58)$. Importantly, diabetic $\mathrm{CD} 40^{-/-}$ mice do not develop capillary degeneration $(6,7)$. Taken together, CD40 is critical for development of various inflammatory responses in the diabetic retina and the development early DR $(6,7)$.

\section{CD40 IN MÜLLER GLIA RECRUITS INFLAMMATORY RESPONSES IN BYSTANDER MICROGLIA/MACROPHAGES}

Leukocytes are recognized key players in the development of inflammatory disorders. Indeed, expression of NOS2 or poly(ADP-ribosyl) polymerase 1 (PARP1) in bone marrow cells is necessary for the development of early DR (66). Similarly, CD40 in hematopoietic cells has been deemed a central driver of inflammation. However, studies in mice using bone marrow chimeras revealed that CD40 expressed in non-hematopoietic cells is also required for inflammation (5). Absence of CD40 in the retina inhibits ICAM-1 mRNA upregulation, leukocyte recruitment to the retina and neurovascular degeneration after $\mathrm{I} / \mathrm{R}$ of the retina (5). Importantly, studies using transgenic mice have established that CD40 expression in a nonhematopoietic cell-Müller glia-is sufficient for development of an inflammatory disorder (7).

Müller glia link with neurons and capillaries, and are central to retina homeostasis $(67,68)$. Müller glia become dysfunctional and acquire expression of proinflammatory genes in diabetic and other ischemic retinopathies (69-71). The fact that Müller glia 
express CD40 raised the possibility that CD40 present in these cells may be an important activator of inflammation and retinal injury. Studies in transgenic mice that expressed CD40 restricted to Müller glia demonstrated that, after induction of diabetes, the presence of CD40 in these cells was sufficient for upregulation of ICAM-1, NOS2, TNF- $\alpha$, IL-1 $\beta$, CCL2 mRNA levels as well as for development of leukostasis and capillary degeneration (7). This work identified CD40 in Müller glia as a central regulator of inflammation and development of early diabetic retinopathy.

Despite the fact that CD40 in Müller glia from diabetic mice drives TNF- $\alpha$ and IL- $1 \beta$ in vivo, work done in vitro revealed that human and rodent Müller glia are unable to secrete these pro-inflammatory cytokines in response to CD40 ligation even though these cells react to CD40 stimulation (CCL2 secretion and ICAM-1 protein upregulation) (7). This apparent discrepancy raised the possibility that CD40 in Müller glia acts on bystander microglia/macrophages to promote expression of TNF- $\alpha$ and IL- $1 \beta$.

Testing whether Müller glia activated by CD40 induce IL$1 \beta$ and TNF- $\alpha$ production in bystander monocytes/macrophages was done by adding human CD154 to human CD40 ${ }^{+}$Müller glia incubated with $\mathrm{CD}^{-} 0^{-}$human monocytic cells (to avoid the effects of direct CD40 ligation on these cells), or by adding human CD154 to human CD40-expressing mouse Müller glia incubated with mouse macrophages (human CD154 does not stimulate mouse CD40 expressed in macrophages) (7). While Müller glia and monocyte/macrophages failed to secrete TNF- $\alpha$ and IL- $1 \beta$ in response to CD154, addition of CD154 to the co-culture of these cells triggered TNF- $\alpha$ and IL- $1 \beta$ production (7). The in vitro studies have an in vivo correlate since diabetic mice that express CD40 restricted to Müller glia upregulate TNF- $\alpha$ protein levels in microglia/macrophages but not in Müller glia while the latter cells upregulate CCL2 protein levels (7). Taken together, these studies revealed that Müller glia activated by CD40 induce proinflammatory responses in bystander microglia/macrophages.

\section{THE CD40-ATP-P2X7 PATHWAY AND INFLAMMATORY RESPONSES IN BYSTANDER MICROGLIA/MACROPHAGES}

ATP functions not only as a neurotransmitter for neurons but can also be secreted by non-excitable cells $(72,73)$. Moreover, various cell types express P2 purinergic receptors. These receptors are divided into ATP-gated ionotropic P2X receptors and metabotropic, G protein-coupled P2Y receptors $(72,73)$. The seven subtypes of $\mathrm{P} 2 \mathrm{X}$ receptors are ligand-gated channels permeable to $\mathrm{Ca}^{2+}, \mathrm{Na}^{+}$, and $\mathrm{K}^{+} . \mathrm{P}_{2} \mathrm{X}_{7}$ receptor is characterized by the ability to form large trans-membrane pores in response to repetitive or prolonged exposure to $\operatorname{ATP}(72,73) . \mathrm{P}_{2} \mathrm{X}_{7}$ receptor is key for IL- $1 \beta$ and TNF- $\alpha$ secretion by microglia/macrophages stimulated with ATP $(74,75)$. Indeed, secretion of ATP by astrocytes may cause $\mathrm{P}_{2} \mathrm{X}_{7}$-dependent microglial activation that would drive neuroinflammatory and degenerative disorders (76).

In vitro and in vivo studies were conducted to determine whether CD40 acts through ATP-P2X 7 signaling to induce cytokine production in bystander myeloid cells. These studies showed that CD40 is an inducer of ATP release in Müller glia (7). Moreover, purinergic signaling explains TNF- $\alpha$ and IL$1 \beta$ secretion in bystander monocytes/macrophages incubated with Müller glia activated by CD40. Blockade of the $\mathrm{P}_{2} \mathrm{X}_{7}$ receptor either by pharmacologic approaches, knockdown of $\mathrm{P}_{2} \mathrm{X}_{7}$ or the use of macrophages from $\mathrm{P} 2 \mathrm{X}_{7}^{-/-}$mice results in marked inhibition of TNF- $\alpha$ and IL-1 $\beta$ secretion (7). In addition, a purinergic receptor ligand (Bz-ATP) enhances cytokine production by monocytic cells (7).

As described above, studies in diabetic transgenic mice that express CD40 only in Müller glia revealed that TNF- $\alpha$ is expressed in a distinct compartment-microglia/macrophages (7). Moreover, $\mathrm{P}_{2} \mathrm{X}_{7}$ receptor mRNA levels are enhanced in the retinas of diabetic mice and $\mathrm{P} 2 \mathrm{X}_{7}$ receptor protein expression is increased in microglia/macrophages from these animals (7). This is relevant since increased levels of $\mathrm{P} 2 \mathrm{X}_{7}$ receptor facilitate the effects of the receptor (77). Mice treated with the $\mathrm{P}_{2} \mathrm{X}_{7}$ receptor inhibitor $\mathrm{BBG}$ as well as $\mathrm{P} 2 \mathrm{X}_{7}^{-/-}$mice are protected from diabetes-induced upregulation of IL- $1 \beta$ and TNF$\alpha$ mRNA levels (7). The mice are also protected from increased expression of ICAM-1 and NOS2, molecules that are upregulated by IL-1 $\beta$ and TNF- $\alpha(78,79)$. Taken together, Müller glia activated by CD40 secrete extracellular ATP and drive P2X 7 receptor-dependent pro-inflammatory cytokine expression in bystander microglia/macrophages in vitro and in vivo (Figure 1 and Table 1). These findings support a model whereby CD40 engagement in non-hematopoietic cells triggers inflammatory

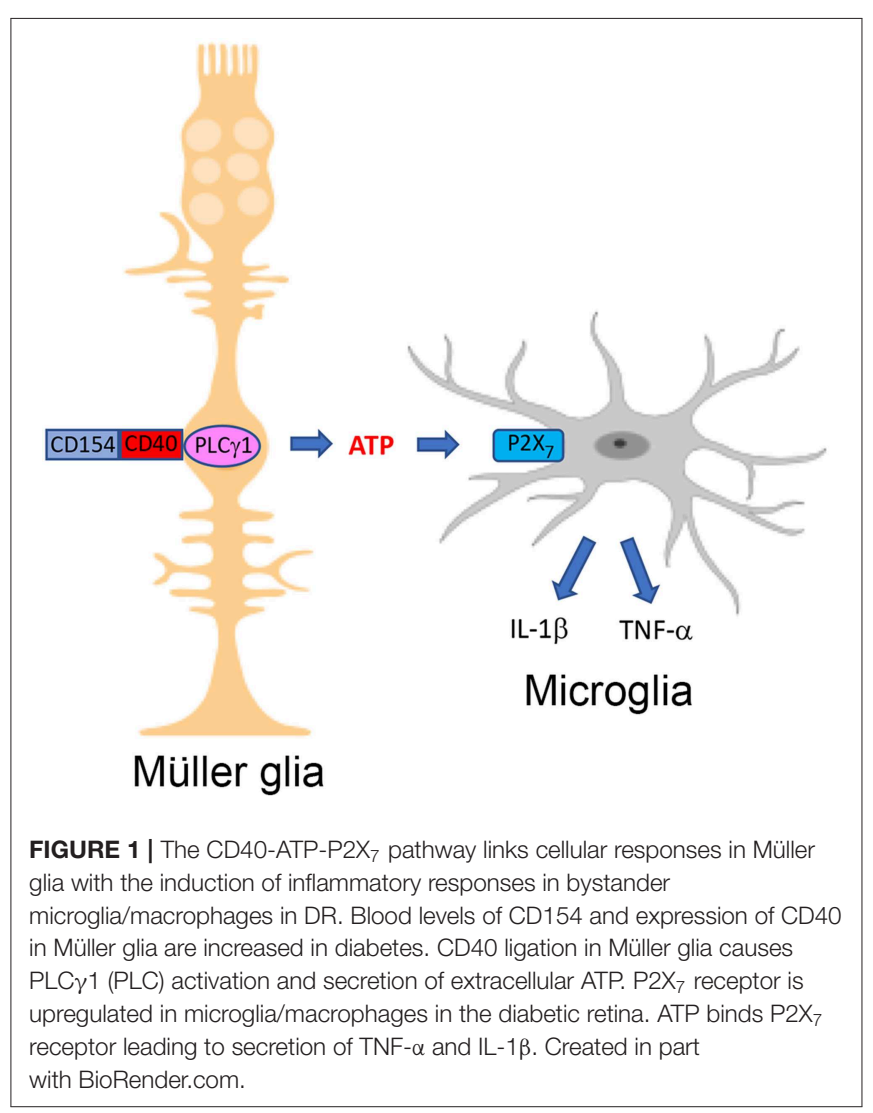


TABLE 1 | Components of the CD40-ATP-P2X 7 pathway in retinopathies.

\begin{tabular}{|c|c|}
\hline Müller glia & Important macroglia in the retina that closely communicates with various retinal cells $(67,68)$ \\
\hline CD40 & $\begin{array}{l}\text { Expressed in Müller glia, retinal endothelial cells, microglia/macrophages, and is upregulated in diabetic and I/R-induced retinopathies } \\
(5,6,55,56)\end{array}$ \\
\hline CD154 & Major ligand of CD40 that is upregulated in plasma and likely in retinal microthrombi in diabetes $(7,63-65)$ \\
\hline PLC $\gamma 1$ & Activated by CD40 ligation in Müller glia and triggers release of extracellular ATP (7) \\
\hline ATP & $\begin{array}{l}\text { Secreted by CD40-activated Müller glia and mediates Müller glia-microglia/macrophages and Müller glia-endothelial cell communication } \\
(7,8)\end{array}$ \\
\hline $\mathrm{P}_{2} \mathrm{X}_{7}$ receptor & $\begin{array}{l}\text { ATP receptor upregulated in microglia and retinal endothelial cells in a CD40-dependent manner. Induces pro-inflammatory cytokine secretion } \\
\text { by macrophages/microglia and programmed cell death in endothelial cells }(7,8)\end{array}$ \\
\hline $\mathrm{TNF}-\alpha / \mathrm{IL}-1 \beta$ & $\begin{array}{l}\text { Upregulated in diabetic and I/R-induced retinopathies, and linked to development of these retinopathies }(33-38,48-50,53) \text {. CD40 promotes } \\
\text { TNF- } \alpha / \mathrm{IL}-1 \beta \text { upregulation (11) }\end{array}$ \\
\hline ICAM-1 & $\begin{array}{l}\text { Upregulated in endothelial cells in diabetic and I/R-induced retinopathies and linked to development of these retinopathies }(3,29,30,49,54) \text {. } \\
\text { CD40 promotes ICAM- } 1 \text { upregulation in retinal endothelial cells }(5,6,58)\end{array}$ \\
\hline CCL2 & $\begin{array}{l}\text { Upregulated in diabetic retinopathy and levels of CCL2 are associated with severity of the disease }(43,44) \text {. CD40 promotes CCL2 production } \\
\text { in endothelial cells and Müller glia }(6,58)\end{array}$ \\
\hline CXCL1 & Upregulated in I/R-induced retinopathy (5). CD40 promotes CXCL1 production by endothelial cells (5) \\
\hline NOS2/COX-2 & $\begin{array}{l}\text { Upregulated in diabetic and/or I/R-induced retinopathies and linked to development of retinopathies }(39-42,49,51,52) \text {. CD40 drives } \\
\text { NOS2/COX-2 upregulation }(5,6)\end{array}$ \\
\hline
\end{tabular}

responses not only in these cells (i.e., chemokine and adhesion molecule upregulation) but also amplifies inflammation by enabling bystander myeloid cells to secrete pro-inflammatory cytokines in a manner dependent on ATP-P2X 7 receptor.

Increased intracytoplasmic $\mathrm{Ca}^{2+}$ triggers ATP release (80) and CD40 elevates intracytoplasmic $\mathrm{Ca}^{2+}$ levels $(81,82)$. Indeed, BAPTA-AM, a chelator of intracellular $\mathrm{Ca}^{2+}$, impairs CD40mediated ATP release in Müller cells (7). In addition, CD40 ligation in Müller glia causes rapid Tyr783 phosphorylation of phospholipase C $\gamma 1$ (PLC $\gamma 1$ ) (7), a signaling molecule that increases intracytoplasmic $\mathrm{Ca}^{2+}$ (83), and pharmacologic inhibition of PLC impairs ATP release by Müller glia activated by CD40 (7). Thus, CD40 ligation phosphorylates PLC $\gamma 1$ and CD40 likely functions via PLC $\gamma 1$ to trigger ATP release in Müller glia.

\section{CD40 IN MÜLLER GLIA AND PROGRAMMED CELL DEATH OF BYSTANDER RETINAL ENDOTHELIAL CELLS}

Retinal endothelial cells undergo programmed cell death (PCD) in the diabetic retina $(32,84-86)$. This process would contribute to the development of capillary degeneration, a central feature of early diabetic retinopathy (32). CD40 is necessary for the development of capillary degeneration $(6,7)$ and yet, ligation of CD40 in endothelial cells does not induce PCD likely because CD40 typically triggers pro-survival signals (87). This raised the possibility of CD40 promoting death of retinal endothelial cells by acting through other cells of the retina. Müller cells were a likely culprit since they encircle retinal endothelial cells.

Whereas direct CD40 ligation in retinal endothelial cells does not cause PCD, CD40 stimulation enhances PCD of endothelial cells when they are incubated with $\mathrm{CD} 40^{+}$Müller cells (8). This effect is not driven by NOS2, oxidative stress, TNF- $\alpha$, IL- $1 \beta$, or
Fas ligand (8). As described above, CD40 ligation in Müller glia increases release of ATP. CD40 ligation in retinal endothelial cells upregulates $\mathrm{P}_{2} \mathrm{X}_{7}$ receptor expression making these cells susceptible to ATP-induced PCD (8). Indeed, pharmacologic inhibition of $\mathrm{P}_{2} \mathrm{X}_{7}$ receptor prevents $\mathrm{PCD}$ of the endothelial cells (8). These results are consistent with the ability of the $\mathrm{P}_{2} \mathrm{X}_{7}$ to form trans-membrane pores that are permeable to hydrophilic molecules of up to $900 \mathrm{Da}(88)$ and mediate cell death $(89,90)$. The in vitro studies described above have an in vivo correlate since retinal $\mathrm{P} 2 \mathrm{X}_{7}$ mRNA levels and $\mathrm{P} 2 \mathrm{X}_{7}$ receptor expression in retinal endothelial cells are increased in diabetic mice in a CD40-dependent manner (8), CD40 appears to be necessary for PCD of retinal endothelial cells from diabetic mice (8), and CD40 is known to be required for retinal capillary degeneration $(6,7)$. Taken together, $\mathrm{CD} 40$ has a dual role in promoting PCD of retinal endothelial cells: it causes release of extracellular ATP by Müller glia and makes retinal endothelial cells susceptible to $\mathrm{P}_{2} \mathrm{X}_{7}$-driven PCD (Figure 2 and Table 1). The latter effect may be explained by $\mathrm{CD} 40$-driven upregulation of the $\mathrm{P}_{2} \mathrm{X}_{7}$ receptor in endothelial cells that would overcome the prosurvival signals activated by CD40 ligation. This mechanism may contribute to increased susceptibility to ATP-mediated PCD that appears to occur in diabetes (91). Other potential mechanisms by which CD40 increases susceptibility to $\mathrm{P}_{2} \mathrm{X}_{7}$ receptor-mediated PCD may include modulation of ATP-gated channel expression, ectoATPase activity, and/or coupling to downstream cell signaling pathways that promote cell death. Finally, while CD40induced activation of ATP-P2 $\mathrm{X}_{7}$ receptor signaling mediates PCD of retinal endothelial cells, CD40 may also promote death of these cells and capillary degeneration through mechanisms that include: enhancement of retinal leukostasis, upregulation of NOS2, TNF- $\alpha$, and IL- $1 \beta$ in the retinas of diabetic mice $(6,7)$, events linked to PCD of retinal endothelial cells and capillary degeneration $(31,37,38,40,42,86)$.

In summary, the studies discussed here discovered the CD40ATP-P2 $\mathrm{X}_{7}$ receptor pathway and revealed that this pathway links 


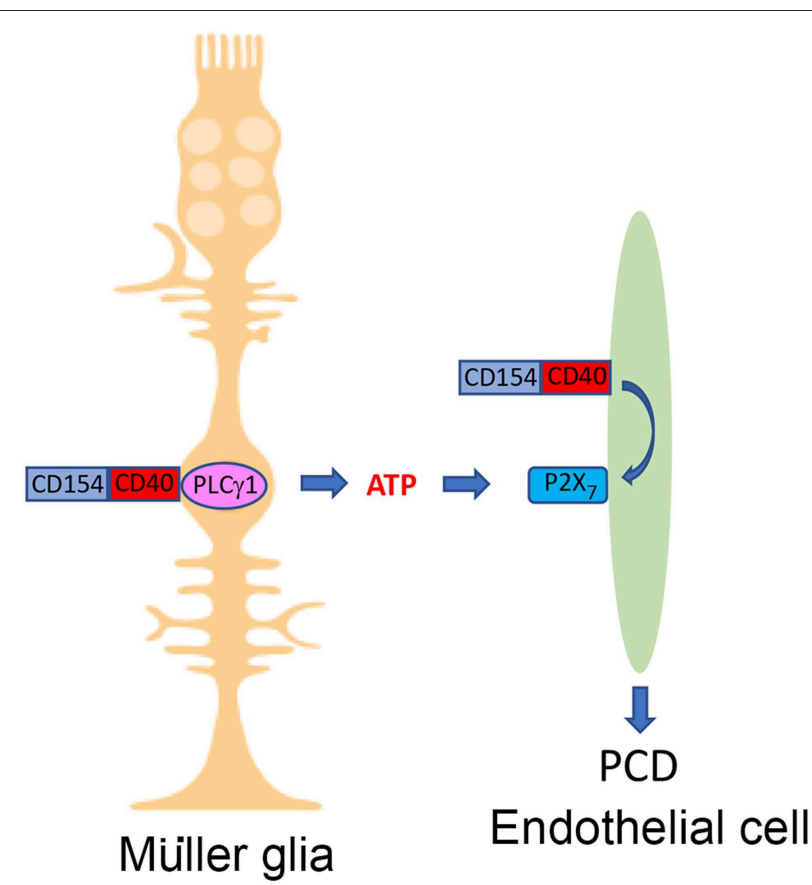

FIGURE 2 | The CD40-ATP-P2X 7 pathway links cellular responses in Müller glia with programmed cell death of bystander retinal endothelial cells in DR. Blood levels of CD154 and expression of CD40 on Müller glia are increased in diabetes. CD40 ligation in Müller glia causes PLC $\gamma 1$ (PLC)-dependent secretion of extracellular ATP. CD40 ligation in retinal endothelial cells upregulates $\mathrm{P} 2 \mathrm{X}_{7}$ receptor, making these cells susceptible to $\mathrm{P} 2 \mathrm{X}_{7}$-induced programmed cell death. Created in part with BioRender.com.

a macroglia to microglia/macrophages and endothelial cells for the induction of inflammatory responses and endothelial cell death, respectively. By enabling myeloid cells to secrete TNF$\alpha$ and IL- $1 \beta$, this process would circumvent the poor capacity of CD40 to directly trigger secretion of these cytokines in nonhematopoietic cells, thus causing amplification of inflammation. These findings may be operative in I/R-induced retinopathy given its similarity to DR. The CD40-ATP-P2X 7 receptor pathway may also be relevant to neuro-inflammatory and neuro-degenerative brain disorders. For example, astrocytes acquire CD40 expression after incubation with IFN- $\gamma$ (92), neural tissue injury or in a transgenic mouse model of amyotrophic lateral sclerosis (93), a disease driven by CD40. Thus, the CD40-ATP-P2X receptor pathway may potentiate pro-inflammatory cytokine production by microglia further driving neuro-inflammation.

\section{REFERENCES}

1. Franke H, Verkhratsky A, Burnstock G, Illes P. Pathophysiology of astroglial purinergic signalling. Purinergic Signal. (2012) 8:629-57. doi: $10.1007 /$ s11302-012-9300-0

2. Tang J, Kern TS. Inflammation in diabetic retinopathy. Prog Retin Eye Res. (2011) 30:343-58. doi: 10.1016/j.preteyeres.2011.05.002

3. Antonetti DA, Klein R, Gardner TW. Diabetic retinopathy. $N$ Engl J Med. (2012) 366:1227-39. doi: 10.1056/NEJMra1005073
Finally, this pathway may be functional in other diseases driven by CD40 such as inflammatory bowel disease, atherosclerosis and lupus nephritis. CD40 present in non-hematopoietic cells of the intestine, blood vessels and kidney may induce release of ATP that would bind purinergic receptors present in infiltrating myeloid cells.

The existence of the CD40-ATP-P2X 7 receptor pathway may have therapeutic implications. Pre-clinical data revealed that administration of anti-CD154 mAb to inhibit CD40CD154 signaling effectively controlled various inflammatory and neurodegenerative disorders (22, 23). Unfortunately, anti-CD154 mAbs caused thromboembolic complications in humans that are unrelated to inhibition of CD40 (94). Targeting signaling pathways downstream of CD40 may represent an alternative approach to treat CD40-driven diseases. CD40 functions by recruiting TNF Receptor Associated Factors (TRAF) to its TRAF2,3 or TRAF6 binding sites (95). Blockade of CD40-TRAF2,3 signaling markedly impairs pro-inflammatory responses in non-hematopoietic cells $(58,96)$. Blocking this signaling pathway may also inhibit pro-inflammatory responses in neighboring myeloid cells. Pharmacologic approaches to inhibit CD40-TRAF2,3 signaling (cell penetrating CD40TRAF2,3 blocking peptide or small molecule CD40-TRAF2,3 inhibitor) may prove an effective approach to treat diabetic and ischemic retinopathies, and potentially other CD40-driven inflammatory disorders. Given that TRAF6 is critical for dendritic cell maturation and development (96, 97), CD40mediated IL-12 production by dendritic cells (98) and induction of antimicrobial effector mechanisms in macrophages $(99,100)$, pharmacologic inhibition of CD40-TRAF2,3 signaling would minimize the risk of opportunistic infections by leaving CD40-TRAF6 signaling intact.

\section{AUTHOR CONTRIBUTIONS}

The author confirms being the sole contributor of this work and has approved it for publication.

\section{FUNDING}

CS was funded by NIH-R01 EY018341 and NIH-R01 EY019250.

\section{ACKNOWLEDGMENTS}

The author thanks all the members of the Subauste lab for their feedback on this manuscript. 
7. Portillo J-AC, Lopez Corcino Y, Miao Y, Tang J, Sheibani N, Kern TS, et al. CD40 in retinal Muller cells induces P2X7-dependent cytokine expression in macrophages/microglia in diabetic mice and development of early experimental diabetic retinopathy in mice. Diabetes. (2017) 66:483-93. doi: $10.2337 / \mathrm{db} 16-0051$

8. Portillo J-A, Lopez Corcino Y, Dubyak GR, Kern TS, Matsuyama S, Subauste CS. Ligation of CD40 in human retinal Muller cells induces P2X7 receptordependent death of retinal endothelial cells. Invest Ophthalmol Vis Sci. (2016) 57:6278-86. doi: 10.1167/iovs.16-20301

9. Clark EA, Ledbetter J. Activation of human B cells mediated through two distinct cell surface differentiation antigens, Bp35 and Bp50. Proc Natl Acad Sci USA. (1986) 83:4494-8. doi: 10.1073/pnas.83.12.4494

10. Karmann K, Hughes CCW, Schechner J, Fanslow WC, Pober JS. CD40 on human endothelial cells: inducibility by cytokines and functional regulation of adhesion molecule expression. Proc Natl Acad Sci USA. (1995) 92:4342-6. doi: 10.1073/pnas.92.10.4342

11. Kiener PA, Moran-Davis P, Rankin BM, Wahl AF, Aruffo A, Hollenbaugh D. Stimulation of CD40 with purified soluble gp39 induces proinflammatory responses in human monocytes. J Immunol. (1995) 155:4917-25.

12. Tan J, Town T, Mori T, Obregon D, Wu Y, Delledonne A, et al. CD40 is expressed and functional on neuronal cells. EMBO J. (2002) 21:643-52. doi: 10.1093/emboj/21.4.643

13. Borcherding F, Nitschke M, Von Smolinski D, Bieber K, Van Kooten $\mathrm{C}$, Lehnert $\mathrm{H}$, et al. The CD40-CD40L pathway contributes to the proinflammatory function of intestinal epithelial cells in inflammatory bowel disease. Am J Pathol. (2010) 176:1816-27. doi: 10.2353/ajpath.2010.090461

14. Van Kooten C, Banchereau J. CD40-CD40 ligand. J Leuk Biol. (2000) 67:2-17. doi: $10.1002 / \mathrm{jlb}$.67.1.2

15. Xu H, Zhang X, Mannon RB, Kirk AD. Platelet-derived or soluble CD154 induces vascularized allograft rejection independent of cell-bound CD154. J Clin Invest. (2006) 116:769-74. doi: 10.1172/JCI27155

16. Levy J, Espanol-Boren T, Thomas C, Fischer A, Tovo P, Bordigoni P, et al. Clinical spectrum of X-linked hyper-IgM syndrome. J Pediatr. (1997) 131:47-54. doi: 10.1016/S0022-3476(97)70123-9

17. Elgueta R, Benson MJ, De Vries VC, Wasiuk A, Guo Y, Noelle RJ. Molecular mechanism and function of CD40/CD40L engagement in the immune system. Immunol Rev. (2009) 229:152-72. doi: 10.1111/j.1600-065X.2009.00782.x

18. Laman JD, Claassen E, Noelle RJ. Functions of CD40 and Its Ligand, gp39 (CD40L). Crit Rev Immunol. (2017) 37:371-420. doi: 10.1615/CritRevImmunol.v37.i2-6.100

19. Ara A, Ahmed KA, Xiang J. Multiple effects of CD40-CD40L axis in immunity against infection and cancer. Immunotargets Ther. (2018) 7:55-61. doi: 10.2147/ITT.S163614

20. Mcwilliams TG, Howard L, Wyatt S, Davies AM. Regulation of autocrine signaling in subsets of sympathetic neurons has regional effects on tissue innervation. Cell Rep. (2015) 10:1443-9. doi: 10.1016/j.celrep.2015.02.016

21. Carriba P, Davies AM. CD40 is a major regulator of dendrite growth from developing excitatory and inhibitory neurons. Elife. (2017) 6:e30442. doi: $10.7554 /$ eLife.30442

22. Mach F, Schonbeck U, Sukhova GK, Atkinson E, Libby P. Reduction of atherosclerosis in mice by inhibition of CD40 signaling. Nature. (1998) 394:200-3. doi: 10.1038/28204

23. Peters AL, Stunz LL, Bishop GA. CD40 and autoimmunity: the dark side of a great activator. Semin Immunol. (2009) 21:293-300. doi: 10.1016/j.smim.2009.05.012

24. Yau JW, Rogers SL, Kawasaki R, Lamoureux EL, Kowalski JW, Bek T, et al. Global prevalence and major risk factors of diabetic retinopathy. Diabetes Care. (2012) 35:556-64. doi: 10.2337/dc11-1909

25. Bourne RR, Stevens GA, White RA, Smith JL, Flaxman SR, Price H, et al. Causes of vision loss worldwide, 1990-2010: a systematic analysis. Lancet Glob Health. (2013) 1:e339-49. doi: 10.1016/S2214-109X(13)70113-X

26. Giacco F, Brownlee M. Oxidative stress and diabetic complications. Circ Res. (2010) 107:1058-70. doi: 10.1161/CIRCRESAHA.110.223545

27. Eid S, Sas KM, Abcouwer SF, Feldman EL, Gardner TW, Pennathur $S$, et al. New insights into the mechanisms of diabetic complications: role of lipids and lipid metabolism. Diabetologia. (2019) 62:1539-49. doi: $10.1007 /$ s00125-019-4959-1
28. Adamiec-Mroczek J, Oficjalska-Mlynczak J, Misiuk-Hojlo M. Proliferative diabetic retinopathy - the influence of diabetes control on the activation of the intraocular molecule system. Diabetes Res Clin Pract. (2009) 84:46-50. doi: 10.1016/j.diabres.2009.01.012

29. Mcleod DS, Lefer DJ, Merges C, Lutty GA. Enhanced expression of intracellular adhesion molecule-1 and P-selectin in the diabetic human retina and choroid. Am J Pathol. (1995) 147:642-53.

30. Miyamoto K, Khorsrof S, Bursell SE, Rohan R, Murata T, Clermont AC, et al. Prevention of leukostasis and vascular leakage in streptozotocin-induced diabetic retinopathy via intercellular adhesion molecule-1 inhibition. Proc Natl Acad Sci USA. (1999) 96:10836-41. doi: 10.1073/pnas.96.19.10836

31. Joussen AM, Poulaki V, Le ML, Koizumi K, Esser C, Janicki H, et al. A central role for inflammation in the pathogenesis of diabetic retinopathy. FASEB J. (2004) 18:1450-2. doi: 10.1096/fj.03-1476fje

32. Mizutani M, Kern TS, Lorenzi M. Accelerated death of retinal microvascular cells in human and experimental diabetic retinopathy. J Clin Invest. (1996) 97:2883-90. doi: 10.1172/JCI118746

33. Krady JK, Basu A, Allen CM, Xu Y, Lanoue KF, Gardner TW, et al. Minocycline reduces proinflammatory cytokine expression, microglial activation, and caspase-3 activation in a rodent model of diabetic retinopathy. Diabetes. (2005) 54:1559-65. doi: 10.2337/diabetes.54. 5.1559

34. Yang L-P, Sun H-L, Wu L-M, Guo X-J, Dou H-L, Tso MOM, et al. Baicalein reduces inflammatory process in a rodent model of diabetic retinopathy. Invest Ophthalmol Vis Sci. (2009) 50:2319-27. doi: 10.1167/iovs.08-2642

35. Vujosevic S, Micera A, Bini S, Berton M, Esposito G, Midena E. Proteome analysis of retinal glia cells-related inflammatory cytokines in the aqueous humour of diabetic patients. Acta Ophthalmol. (2016) 94:56-64. doi: 10.1111/aos.12812

36. Boss JD, Singh PK, Pandya HK, Tosi J, Kim C, Tewari A, et al. Assessment of neurotrophins and inflammatory mediators in vitreous of patients with diabetic retinopathy. Invest Ophthalmol Vis Sci. (2017) 58:5594-603. doi: 10.1167/iovs.17-21973

37. Vincent JA, Mohr S. Inhibition of caspase-1/interleukin-1 $\beta$ signaling prevents degeneration of retinal capillaries in diabetes and galactosemia. Diabetes. (2007) 56:224-30. doi: 10.2337/db06-0427

38. Joussen AM, Doehmen S, Le ML, Koizumi K, Radetzky S, Krohne TU, et al. TNF- $\alpha$ mediated apoptosis plays an important role in the development of early diabetic retinopathy and long-term histopathological alterations. Mol Vision. (2009) 15:1418-28.

39. Abu El-Asrar AM, Desmet S, Meersschaert A, Dralands L, Missotten L, Geboes K. Expression of the inducible isoform of nitric oxide synthase in the retinas of human subjects with diabetes mellitus. Am J Ophthalmol. (2001) 132:551-6. doi: 10.1016/S0002-9394(01)01127-8

40. Du Y, Smith MA, Miller CM, Kern TS. Diabetes-induced nitrative stress in the retina, and correction by aminoguanidine. J Neurochem. (2002) 80:771-9. doi: 10.1046/j.0022-3042.2001.00737.x

41. Leal EC, Manivannan A, Hosoya K-I, Terasaki T, Cunha-Vaz J, Ambrosio $\mathrm{AF}$, et al. Inducible nitric oxide synthase isoform is a key mediator of leukostasis and blood-retinal barrier breakdown in diabetic retinopathy. Invest Ophthalmol Vis Sci. (2007) 48:5257-65. doi: 10.1167/iovs.07-0112

42. Zheng L, Du Y, Miller C, Gubitosi-Klug RA, Kern TS, Ball S, et al. Critical role of inducible nitric oxide synthase in degeneration of retinal capillaries in mice with streptozotocin-induced diabetes. Diabetologia. (2007) 50:1987-96. doi: 10.1007/s00125-007-0734-9

43. Taghavi Y, Hassanshahi G, Kounis NG, Koniari I, Khorramdelazad H. Monocyte chemoattractant protein-1 (MCP-1/CCL2) in diabetic retinopathy: latest evidence and clinical considerations. J Cell Commun Signal. (2019) 1-12. doi: 10.1007/s12079-018-00500-8

44. Zhang SX, Wang JJ, Gao G, Shao C, Mott R, Ma J-X. Pigmented epitheliumderived factor (PEDF) is na endogenous antiinflammatory factor. FASEB J. (2006) 20:323-5. doi: 10.1096/fj.05-4313fje

45. Gilbert C, Rahi J, Eckstein M, O’sullivan J, Foster A. Retinopathy of prematurity in middle-income countries. Lancet. (1997) 350:12-4. doi: 10.1016/S0140-6736(97)01107-0

46. Varma DD, Cugati S, Lee AW, Chen CS. A review of central retinal artery occlusion: clinical presentation and management. Eye. (2013) 27:688-97. doi: 10.1038 /eye. 2013.25 
47. Ashraf M, Souka AA, Singh RP. Central retinal vein occlusion: modifying current treatment protocols. Eye. (2016) 30:505-14. doi: 10.1038/eye.2016.10

48. Rivera JC, Dabouz R, Noueihed B, Omri S, Tahiri H, Chemtob S. Ischemic retinopathies: oxidative stress and inflammation. Oxid Med Cell Longev. (2017) 2017:3940241. doi: 10.1155/2017/3940241

49. Zheng L, Gong B, Hatala DA, Kern TS. Retinal ischemia and reperfusion causes capillary degeneration: similarities to diabetes. Invest Ophthalmol Vis Sci. (2007) 48:361-7. doi: 10.1167/iovs.06-0510

50. Yoneda S, Tanihara H, Kido N, Honda Y, Goto W, Hara H, et al. Interleukin-1 beta mediates ischemic injury in the rat retina. Exp Eye Res. (2001) 73:661-7. doi: 10.1006/exer.2001.1072

51. Neufeld AH, Kawai S, Das S, Vora S, Gachie E, Connor JR, et al. Loss of retinal ganglion cells following retinal ischemia: the role of inducible nitric oxide synthase. Exp Eye Res. (2002) 75:521-8. doi: 10.1006/exer. 2002.2042

52. Choi JS, Kim D, Hong YM, Mizuno S, Joo CK. Inhibition of nNOS and COX2 expression by lutein in acute retinal ischemia. Nutrition. (2006) 22:668-71. doi: 10.1016/j.nut.2005.08.011

53. Vinores SA, Xiao WH, Shen J, Campochiaro PA. TNF- $\alpha$ is critical for ischemia-induced leukostasis, but not retinal neovascularization nor VEGF-induced leakage. J. Neuroimmunol. (2007) 182:73-9. doi: 10.1016/j.jneuroim.2006.09.015

54. Tsujikawa A, Ogura Y, Hiroshiba N, Miyamoto K, Kiryu J, Tojo SJ, et al. Retinal ischemia-reperfusion injury attenuated by blocking of adhesion molecules of vascular endothelium. Invest Ophthalmol Vis Sci. (1999) 40:1183-90.

55. Portillo J-AC, Okenka G, Kern TS, Subauste CS. Identification of primary retinal cells and ex vivo identification of pro-inflammatory molecules in retinal cells using flow cytometry. Mol Vis. (2009) 15:1383-9.

56. Van Grol J, Muniz-Feliciano L, Portillo J-AC, Bonilha VL, Subauste CS. CD40 induces anti-Toxoplasma gondii activity in non-hematopoietic cells dependent on autophagy proteins. Infect Immun. (2013) 81:2002-11. doi: 10.1128/IAI.01145-12

57. Yellin MJ, D'agati V, Parkinson G, Han AS, Szema A, Baum D, et al. Immunohistologic analysis of renal CD40 and CD40L expression in lupus nephritis and other glomerulonephritis. Arthritis Rheum. (1997) 40:124-34. doi: 10.1002/art.1780400117

58. Portillo J-A, Schwartz I, Zarini S, Bapputy R, Kern TS, Gubitosi-Klug $\mathrm{RA}$, et al. Pro-inflammatory responses induced by CD40 in retinal endothelial and Muller cells are inhibited by blocking CD40-TRAF2,3 or CD40-TRAF6 signaling. Invest Ophthalmol Vis Sci. (2014) 55:8590-7. doi: 10.1167/iovs.14-15340

59. Kuo HL, Huang CC, Lin TY, Lin CY. IL-17 and CD40 ligand synergistically stimulate the chronicity of diabetic nephropathy. Nephrol Dial Transplant. (2018) 33:248-56. doi: 10.1093/ndt/gfw397

60. Chatzigeorgiou AE, Lembessis PE, Mylona-Karagianni CF, Tsouvalas EA, Diamanti-Kandarakis E, Kamper EF. CD40 expression and its association with low-grade inflammation in a Greek population of type 1 diabetic juveniles: evidence for differences in CD40 mRNA isoforms expressed by peripheral blood mononuclear cells. Exp Clin Endocrinol Diabetes. (2010) 118:38-46. doi: 10.1055/s-0029-1224151

61. Yan S, Yim LY, Tam RC, Chan A, Lu L, Lau CS, et al. MicroRNA-155 mediates augmented CD40 expression in bone marrow derived plasmacytoid dendritic cells in symptomatic lupus-prone NZB/W F1 mice. Int J Mol Sci. (2016) 17:E1282. doi: 10.3390/ijms17081282

62. Lee A, Papangeli I, Park Y, Jeong HN, Choi J, Kang H, et al. A PPAR $\gamma$-dependent miR-424/503-CD40 axis regulates inflammation mediated angiogenesis. Sci Rep. (2017) 7:2528. doi: 10.1038/s41598-01702852-4

63. Cipollone F, Chiarelli F, Davi G, Ferri C, Desideri G, Fazia M, et al. Enhanced soluble CD40 ligand contributes to endothelial cell dysfunction in vitro and monocyte activation in patients with diabetes mellitus: effect of improved metabolic control. Diabetologia. (2005) 48:1216-24. doi: $10.1007 / \mathrm{s} 00125-005-1750-2$

64. Lamine LB, Turki A, Al-Khateeb G, Sellami N, Amor HB, Sarray S, et al. Elevation in circulating soluble CD40 ligand concentrations in type 2 diabetic retinopathy and association with its severity. Exp Clin Endocrinol Diabetes. (2018). doi: 10.1055/a-0647-6860
65. Boeri D, Maiello M, Lorenzi M. Increased prevalence of microthromboses in retinal capillaries of diabetic individuals. Diabetes. (2001) 50:1432-9. doi: 10.2337/diabetes.50.6.1432

66. Li G, Veenstra AA, Talahalli RR, Wang X, Gubitosi-Klug RA, Sheibani $\mathrm{N}$, et al. Marrow-derived cells regulate the devlopment of early diabetic retinopathy and tactile allodynia in mice. Diabetes. (2012) 61:3294-303. doi: $10.2337 / \mathrm{db} 11-1249$

67. Bringmann A, Pannicke T, Grosche J, Francke M, Widemann P, Skatchkov SN, et al. Muller cells in the healthy and diseases retina. Prog Retin Eye Res. (2006) 25:397-424. doi: 10.1016/j.preteyeres.2006.05.003

68. Devoldere J, Peynshaert K, De Smedt SC, Remaut K. Muller cells as a target for retinal therapy. Drug Discov Today. (2019) 24:1483-98. doi: 10.1016/j.drudis.2019.01.023

69. Gerbardinger C, Biarnes Costa M, Coulombe MC, Toth I, Hoehn T, Grosu P. Expression of acute-phase response proteins in retinal Muller cells in diabetes. Invest Ophthalmol Vis Sci. (2005) 46:349-57. doi: $10.1167 /$ iovs.04-0860

70. Powers MR, Davies MH, Eubanks JP. Increased expression of chemokine KC an interleukin-8 homologue, in a model of oxygen-induced retinopathy. Curr Eye Res. (2005) 30:299-307. doi: 10.1080/02713680590923276

71. Wang J, Xu X, Elliot MH, Zhu M, Le Y-Z. Muller cell-derived VEGF is essential for diabetes-induced retinal inflammation and vascular leakage. Diabetes. (2010) 59:2297-305. doi: 10.2337/db09-1420

72. James G, Butt AM. P2Y and P2X purinoceptor mediated Ca2+ signalling in glial cell pathology in the central nervous system. Eur J Pharmacol. (2002) 447:247-60. doi: 10.1016/S0014-2999(02)01756-9

73. Fields RD, Burnstock G. Purinergic signalling in neuron-glia interactions. Nat Rev Neurosci. (2006) 7:423-36. doi: 10.1038/nrn1928

74. Ferrari D, Chiozzi P, Falzoni S, Dal Susino M, Melchiorri L, Baricordi OR, et al. Extracellular ATP triggers IL-1 beta release by activating the purinergic P2Z receptor of human macrophages. J Immunol. (1997) 159:1451-8.

75. Hide I, Tanaka $\mathrm{M}$, Inoue $\mathrm{A}$, Nakajima $\mathrm{K}$, Kohsaka $\mathrm{S}$, Inoue $\mathrm{K}$, et al. Extracellular ATP triggers tumor necrosis factor-alpha release from rat microglia. $J$ Neurochem. (2000) 75:965-72. doi: 10.1046/j.1471-4159.2000.0750965.x

76. Monif M, Burnstock G, Williams DA. Microglia: proliferation and activation driven by the P2X7 receptor. Int J Biochem Cell Biol. (2010) 42:1753-6. doi: 10.1016/j.biocel.2010.06.021

77. Monif M, Reid CA, Powell KL, Smart ML, Williams DA. The P2X7 receptor drives microglial activation and proliferation: a trophic role for P2X7R pore. J Neurosci. (2009) 29:3781-91. doi: 10.1523/JNEUROSCI.5512-08.2009

78. Liu J, Zhao ML, Brosnan CF, Lee SC. Expression of type II nitric oxide synthase in primary human astrocytes and microglia: role of IL-1beta and IL-1 receptor antagonist. J Immunol. (1996) 157:3569-76.

79. Joussen AM, Poulaki V, Mitsiades N, Kirchhoff B, Koizumi K, Dohmen $S$, et al. Nonsteroidal anti-inflammatory drugs prevent early diabetic retinopathy via TNF- $\alpha$ suppression. FASEB J. (2002) 16:438-40. doi: 10.1096/fj.01-0707fje

80. Bal-Price A, Moneer Z, Brown GC. Nitric oxide induces rapid, calciumdependent release of vesicular glutamate and ATP from cultured rat astrocytes. Glia. (2002) 40:312-23. doi: 10.1002/glia.10124

81. Klaus GG, Choi MS, Holman M. Properties of mouse CD40. Ligation of CD40 activates $\mathrm{B}$ cells via a $\mathrm{Ca}(++)$-dependent, FK506-sensitive pathway. Eur J Immunol. (1994) 24:3229-32. doi: 10.1002/eji.1830241248

82. Lazaar AL, Amrani Y, Hsu J, Panettieri RA Jr, Fanslow WC, Albelda SM, et al. CD40-mediated signal transduction in human airway smooth muscle. J Immunol. (1998) 161:3120-7.

83. Yang YR, Follo MY, Cocco L, Suh PG. The physiological roles of primary phospholipase C. Adv Biol Regul. (2013) 53:232-41. doi: 10.1016/j.jbior.2013.08.003

84. Kern TS, Tang J, Mizutani M, Kowluru RA, Nagaraj RH, Romeo G, et al. Response of capillary cell death to aminoguanidine predicts the development of retinopathy: comparison of diabetes and galactosemia. Invest Ophthalmol Vis Sci. (2000) 41:3972-8.

85. Joussen AM, Poulaki V, Mitsiades N, Cai W-Y, Suzuma I, Pak J, et al. Suppression of Fas-FasL-induced endothelial cell apoptosis prevents diabetic blood-retinal barrier breakdown in a model of streptozotocin-induced diabetes. FASEB J. (2002) 17:76-8. doi: 10.1096/fj.02-0157fje 
86. Behl Y, Krothapalli P, Desta T, Dipiazza A, Roy S, Graves DT. Diabetes-enhanced tumor necrosis factor-alpha production promotes apoptosis and the loss of retinal microvascular cells in type 1 and type 2 models of diabetic retinopathy. Am J Pathol. (2008) 172:1411-8. doi: 10.2353/ajpath.2008.071070

87. Deregibus MC, Buttiglieri S, Russo S, Bussolati B, Camussi G. CD40dependent activation of phosphatidylinositol 3-kinase/Akt pathway mediates endothelial cell survival and in vitro angiogenesis. J Biol Chem. (2003) 278:18008-14. doi: 10.1074/jbc.M300711200

88. Surprenant A, Rassendren F, Kawashima E, North RA, Buell G. The cytolytic P2Z receptor for extracellular ATP identified as a P2X receptor (P2X7). Science. (1996) 272:735-8. doi: 10.1126/science.272. 5262.735

89. Di Virgilio F, Chiozzi P, Falzoni S, Ferrari D, Sanz JM, Venketaraman V, et al. Cytolytic P2X purinoceptors. Cell Death Differ. (1998) 5:191-9. doi: $10.1038 /$ sj.cdd.4400341

90. Jun DJ, Kim J, Jung SY, Song R, Noh JH, Park YS, et al. Extracellular ATP mediates necrotic cell swelling in SN4741 dopaminergic neurons through P2X7 receptors. J Biol Chem. (2007) 282:37350-8. doi: 10.1074/jbc.M707915200

91. Sugiyama T. Enhancement of of P2X7-induced pore formation and apoptosis: an early effect of diabetes on the retinal microvasculature. Invest Ophthalmol Vis Sci. (2004) 45:1026-32. doi: 10.1167/iovs. 03-1062

92. Tan L, Gordon KB, Mueller JP, Matis LA, Miller SD. Presentation of proteolipid protein epitopes and B7-1-dependent activation of encephalitogenic $\mathrm{T}$ cells by IFN- $\gamma$-activated SJL/J astrocytes. J Immunol. (1998) 160:4271-9.

93. Okuno T, Nakatsuji Y, Kumanogoh A, Koguchi K, Moriya M, Fujimura $\mathrm{H}$, et al. Induction of cyclooxygenase- 2 in reactive glial cells by the CD40 pathway: relevance to amyotrophic lateral sclerosis. J Neurochem. (2004) 91:404-12. doi: 10.1111/j.1471-4159.2004.02727.x

94. Boumpas DT, Furie R, Manzi S, Ilei GG, Wallace DJ, Balow JE, et al. A short course of BG9588 (anti-CD40 ligand antibody) improves serologic activity and decreases hematuria in patients with proliferative lupus glomerulonephritis. Arthritis Rheum. (2003) 48:719-27. doi: 10.1002/art.10856

95. Bishop GA, Hostager BS, Brown KD. Mechanisms of TNF receptorassociated factor (TRAF) regulation in B lymphocytes. J Leuk Biol. (2002) 72:19-23. doi: 10.1189/jlb.72.1.19

96. Portillo J-AC, Greene JA, Schwartz I, Subauste MC, Subauste CS. Blockade of CD40-TRAF2,3 or CD40-TRAF6 interactions is sufficient to impair pro-inflammatory responses in human aortic endothelial cells and human aortic smooth muscle cells. Immunology. (2015) 144:21-33. doi: 10.1111/imm.12361

97. Kobayashi T, Walsh PT, Walsh MC, Speirs KM, Chiffoleau E, King CG, et al. TRAF6 is a critical factor for dendritic cell maturation and development. Immunity. (2003) 19:353-63. doi: 10.1016/S1074-7613(03)00230-9

98. Mackey MF, Wang Z, Eichelberg K, Germain RN. Distinct contributions of different CD40 TRAF binding sites to CD154-induced dendritic cell maturation and IL-12 secretion. Eur J Immunol. (2003) 33:779-89. doi: 10.1002/eji.200323729

99. Andrade RM, Wessendarp M, Portillo J-AC, Yang J-Q, Gomez FJ, Durbin JE, et al. TRAF6 signaling downstream of CD40 primes macrophages to acquire anti-microbial activity in response to TNF- $\alpha$. J. Immunol. (2005) 175:6014-21. doi: 10.4049/jimmunol.175.9.6014

100. Portillo J-AC, Muniz-Feliciano L, Subauste MC, Heinzel FP, Subauste CS. CD40 and TNF- $\alpha$ synergize to induce nitric oxide synthase in macrophages. Immunology. (2012) 135:140-50. doi: 10.1111/j.1365-2567.2011.03519.x

Conflict of Interest: The author declares that the research was conducted in the absence of any commercial or financial relationships that could be construed as a potential conflict of interest.

Copyright (c) 2019 Subauste. This is an open-access article distributed under the terms of the Creative Commons Attribution License (CC BY). The use, distribution or reproduction in other forums is permitted, provided the original author(s) and the copyright owner(s) are credited and that the original publication in this journal is cited, in accordance with accepted academic practice. No use, distribution or reproduction is permitted which does not comply with these terms. 